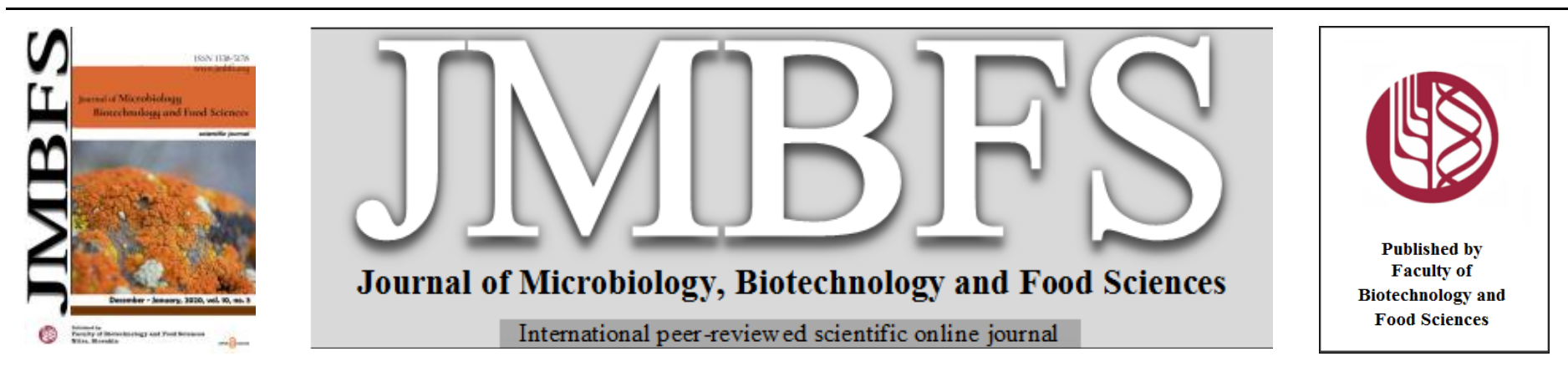

\title{
TECHNOLOGICAL, ANTIOXIDANT, ANTIMICROBIAL AND SENSORY PROFILES OF SELECTED KINDS OF GRAPE OILS
}

\author{
Veronika Juricová $^{1 *}$, Eva Ivanišová ${ }^{2}$, Július Arvay $^{3}$, Lucia Godočíkovál ${ }^{1}$, Miroslava Kačániová4,5
}

\section{Address(es):}

${ }^{1}$ Department of Microbiology, Faculty of Biotechnology and Food Sciences, Slovak University of Agriculture in Nitra, Tr. A. Hlinku 2, SK-949 76, Slovakia

${ }^{2}$ Department of Technology and Quality of Plant Products, Faculty of Biotechnology and Food Sciences, Slovak University of Agriculture in Nitra, Tr. A. Hlinku 2, SK-949 76, Slovakia.

${ }^{3}$ Department of Chemistry, Faculty of Biotechnology and Food Sciences, Slovak University of Agriculture in Nitra, Tr. A. Hlinku 2, SK-949 76, Slovakia.

${ }^{4}$ Department of Fruit Science, Viticulture and Enology, Faculty of Horticulture and Landscape Engineering, Slovak University of Agriculture, Tr. A. Hlinku 2, SK94976 Nitra, Slovakia.

${ }^{5}$ Department of Bioenergetics, Food Analysis and Microbiology, Institute of Food Technology and Nutrition, University of Rzeszow, Cwiklinskiej 1, 35-601, Rzeszow, Poland.

*Corresponding author: xjuricova@is.uniag.sk

doi: 10.15414/jmbfs.2020.10.3.500-504

\section{ARTICLE INFO}

Received 22.7. 2020

Revised 10.9. 2020

Accepted 22. 10. 2020

Published 1. 12. 2020

Regular article open $\mathcal{O}_{\text {ACCESS }}$

\begin{abstract}
The aim of this study was to determine technological (fat content, acid number, peroxide value, oxidation stability, fatty acid profiles), antioxidant (DPPH method), antimicrobial activity (antibacterial and antifungal) and sensory profiles of 4 kinds of Slovak grape seed oils (commercial, oil from white grape variety, oil from blue grape variety and oil made from grape after alcoholic fermentation). The fat content ranged from $95.86 \%$ (blue grape variety oil) to $98.23 \%$ (commercial oil). The values of acid number ranged from $0.15 \mathrm{mg}$ KOH. ${ }^{-1}$ (blue grape variety oil) to $0.90 \mathrm{mg} \mathrm{KOH} . \mathrm{g}^{-1}$ (commercial oil) and of peroxide number from $2.75 \mathrm{mmol} \mathrm{O}_{2} . \mathrm{kg}^{-1}$ (blue grape variety oil) to $8.91 \mathrm{mmol} \mathrm{O}_{2} \cdot \mathrm{kg}^{-1}$ (commercial oil). Values of antioxidant activity (DPPH method) ranged from $47.61 \mathrm{mg}$ TEAC. $\mathrm{l}^{-1}$ (commercial oil) to $75.30 \mathrm{mg}$ TEAC. $\mathrm{l}^{-1}$ (blue grape variety oil) and oxidation stability from $2.75 \mathrm{~h}$ (commercial oil) to $8.91 \mathrm{~h}$ (blue grape variety oil). The predominant acid in all samples was essential omega- 6 fatty acid linoleic acid, which can decrease the cholesterol levels and it is necessary for the activity of cell membranes. Its content differed from $69.43 \pm 0.00 \%$ in commercial oil to $72.75 \pm 0.04 \%$ in blue grape variety oil. Grape oils inhibited microscopic fungi (Candida albicans), gramnegative G- (Yersinia enterocolitica, Salmonella enterica subs. enterica) and grampositive $\mathrm{G}^{+}$(Bacillus cereus, Staphylococcus aureus subs. aureus) bacteria. Sensory analysis of tested oils was evaluated good, with the best results in commercial oil, especially consistency and overall appearance. The results of this work characterize and accentuate the qualities of edible grape oils, as a nutritionally valuable food for the nutrition of the human organism.
\end{abstract}

Keywords: oils, fatty acids, antioxidant activity, antimicrobial activity, Rancimat

\section{INTRODUCTION}

Fats are one of the main nutrients essential for human nutrition and the proper functioning of the body. They fulfill many important functions in the body, they are a source of energy, they participate in the construction of cell membranes, they are a source of fat-soluble vitamins, antioxidants or other biologically active substances (ISEO, 2016). According to the previous findings, fats should account for $30 \%$ to $35 \%$ of the total energy received per day, of which $2 / 3$ should be vegetable fats or oils and the remaining 1/ 3 of fats of animal origin (Augustín, 2010). Babinská $\boldsymbol{e t}$ al. (2012) noted that vegetable oils are characterized by a high content of polyunsaturated fatty acids, of which essential fatty acids play an important role, which the human body cannot produce alone and therefore must be taken through diet. Linoleic acid is found in vegetable oils, with a high content of grape oil (Augustín, 2010). The primary source of these essential fatty acids is exclusively vegetable oils. The quality of the fats depends mainly on the composition of the fatty acids and their ratio, on the content of biologically active substances, but also on the method of oil production or processing. Virgin or cold pressed oils are produced to preserve as many bioactive substances as possible by using a gentle low temperature process (Ogrodowska et al., 2017). However, due to the content of these substances, they are more prone to deterioration, so they should be consumed fresh and suitably stored (EFISC Guide, 2014). Grape seed oils include about poly- and monounsaturated fatty acids as in the amount of $90 \%$ particularly of linoleic acid $(58-78 \%$, C18:2) followed by oleic acid (3$15 \%, \mathrm{C} 18: 1)$ and minor amounts of saturated fatty acids (10\%). Polyunsaturated fatty acids such as linoleic acid are referred to in the literature as desirable compounds in the human diet because of their effect in reducing the risk of coronary heart diseases and cancer (Konuskan et al., 2018).

The objective of this study was to point out and evaluate the technological, DPPH scavenging activity, antimicrobial and sensory properties of various types of grape edible oils.

\section{MATERIAL AND METHODS}

\section{Chemicals}

All the chemicals used were of analytical grade and were purchased from SigmaAldrich (Germany), CentralChem (Slovakia) and Supelco (USA).

\section{Material}

Four samples of edible grape oils were analyzed - commercial oil, oil from white grape variety, oil from red grape variety and oil made from grape after alcoholic fermentation. Three samples came from a local producer from the Slovak Republic, which uses grape seeds, forming waste material in wine production, to produce grape oil. All the edible oils analyzed were obtained by "cold pressing" technology. It is a gentle way of producing edible oils, at a temperature of not more than $50^{\circ} \mathrm{C}$, so they are referred to as 'Virgin oils'. 


\section{Determination of acid number}

The $5 \mathrm{~g}$ of sample was weighed into an Erlenmeyer flask, then for each sample, $100 \mathrm{ml}$ of a mixture of equal volumes of ethanol and chloroform were prepared and neutralized to the indicator phenolphthalein to a slightly pink colour with 3 $\%$ ethanolic potassium hydroxide solution. The prepared dissolution system was poured into a sample and the mixture was gently heated to boiling. After mixing 5 drops of phenolphthalein indicator were added and the contents were titrated with 0.1 mol. $\mathrm{l}^{-1}$ ethanolic potassium hydroxide solution with hot and continuous stirring until a pinkish colour was observed for $30 \mathrm{~s}$. The assay was performed 3 times for each sample (Př́íbela, 1993)

\section{Determination of peroxide number}

In a volumetric flask, $75 \mathrm{ml}$ of a 1:1.5 mixture of chloroform and acetic acid was prepared, than $8 \mathrm{~g}$ of the sample was weighed into an Erlenmeyer flask and $25 \mathrm{~m}$ mixture of chloroform-acetic acid was added. The contents were heated to not more than $40{ }^{\circ} \mathrm{C}$ to dissolve the sample. Then $1 \mathrm{ml}$ of potassium iodide solution was added. The sealed flask was placed in the dark for $20 \mathrm{~min}$. Subsequently, 50 $\mathrm{ml}$ of distilled water was added, the contents were mixed; $5 \mathrm{ml}$ of starch oil was added and mixed again. The contents of the flask were titrated with sodium thiosulphate solution $0.02 \mathrm{M}$ until discolouration. The test was performed 3 times for each sample (Př́ibela, 1993).

\section{Determination of fat content}

The fat content of the samples was determined using a fat extractor AncomXT15 (ANKOM Technology, New York, USA) using the manufacturer's recommended methodology. Petroleum ether was used as the extraction agent. Each sample was weighed $1.5 \mathrm{~g}$ (per cellit) into special bags (XT4 filter bag) and then closed with a melter. Sample bags were dried in an oven (WTB, Binder, Germany) at $105{ }^{\circ} \mathrm{C}$ for 3 hours. Then, they were placed in a desiccator and then weighed. Subsequently, they were placed on an apparatus where extraction with petroleum ether was carried out at $90{ }^{\circ} \mathrm{C}$ for 60 minutes. After extraction, the bags were again dried in an oven (WTB, Binder, Germany) at $105{ }^{\circ} \mathrm{C}$ for 30 minutes, placed in a desiccator and weighed. The test was performed in two replicates.

\section{Determination of antioxidant activity - DPPH method}

The 3,6 $\mathrm{ml}$ of DPPH radical $(0.025 \mathrm{~g}$ was dissolved in $100 \mathrm{ml}$ of ethanol and then diluted as necessary) and $0.4 \mathrm{ml}$ of the sample was pipetted into a cuvette. The mixture was rapidly mixed, centrifuged (VS-100 BN 14000 RPM) and placed in the dark for 10 minutes. Subsequently, the decrease in absorbance on the spectrophotometer (Jenway $6405 \mathrm{UV} / \mathrm{Vis}$ ) was monitored at $515 \mathrm{~nm}$ Antioxidant activity was expressed on the basis of the Trolox calibration curve (TEAC) in mg TEAC per litre sample (10-100 mg. $\left.\mathrm{l}^{-1} ; \mathrm{R}^{2}=0.9881\right)$ Measurements were repeated 3 times (Sanchez-Moreno et al., 1998).

\section{Determination of oxidation stability by Rancimat method}

The method is based on an accelerated process of oxidation and volatile formation by exposing samples to elevated temperatures with simultaneous air injection. The time required for measurement is usually several hours instead of weeks or months. The method simulates an accelerated aging process. The volatile oxidation products are transferred to the vessel by a stream of air where they are absorbed in the measuring solution (distilled water), where the conductivity of the measuring solution is continuously recorded. The measurement was carried out on a Rancimat 893 (Metrohm, Switzerland), which works and records the entire measurement process using the Stabnet 893 software. The measurement results are a software curves with induction time.

\section{Determination of fatty acid methyl esters content by GC-FID method}

Prepared, esterified oil samples should be diluted 1: $19(50 \mu 1$ FAME + $950 \mu 1 \mathrm{~N}-$ hexane) before analysis. The qualitative and quantitative determination of FAME was performed by gas chromatography detection on a flame ionization detector on an AGILENT 7890B (Agilent Technologies USA). The $1 \mu 1$ of the diluted sample was injected with the CombiPAL autosampler into the instrument. Separation of fatty acid methyl esters was performed on a HP-88 GC capillary column (Agilent Technologies USA, $60 \mathrm{~m} \mathrm{x} 0.25 \mathrm{~mm}$ x 0,20 $\mu \mathrm{m}$ ). All analytical gases used ( $\mathrm{He}, \mathrm{N}_{2}, \mathrm{H}_{2}$, synthetic air) had a purity of 5.0. Detection of separated components was performed using a flame ionization detector. The data was processed online using Agilent OpenLab ChemStation.Standardization and instrument calibration was performed using a 37-component Supelco 37 Component FAME Mix (CRM, TraceCERT, Supelco USA). The qualitative determination of chromatographic analyzes by GC-Fit method was performed by Agilent 5977A MSD mass spectrometry. The data obtained were compared with the spectral data of the NIST 14.L.
Determination of antibacterial and antifungal properties of edible vegetable oils by selected microorganisms using disc diffusion method

The disc diffusion method is one of the qualitative methods for determining the susceptibility of microbial strains to antimicrobial agents. Depending on the size of the inhibitory zones formed around the disks soaked in the antimicrobial on the solid soil, the strains can be divided into sensitive or resistant ones. The disc diffusion method does not determine the degree of sensitivity of individual strains merely to whether the microorganisms are sensitive or resistant to selected test substances. A Petri dish filled with Mueller-Hinton agar was used for each bacterial strain. A Petri dish filled with Sabouraud agar was used for yeast strain. Analyzes were done in three replicates. The following strains obtained from the Czech collection of microorganisms (Brno, Czech Republic) were studied: Escherichia coli CCM 3954, Haemophilus influenzae CCM 4454, Klebsiella pneumoniae CCM 2318, Yersinia pneumoniae CCM 2318, Salmonella enterica subs. enterica CCM 3807, Bacillus cereus CCM 2010, Staphylococcus aureus subs. aureus CCM 2461, Clostridium perfringens CCM 4435, Streptococcus pneumoniae CCM 4501, Candida albicans CCM 8186.

\section{Sensory evaluation of oils}

Sensory analysis of edible grape oils was carried out by twelve evaluators (aged 25 to $65 ; 7$ women and 5 men). The panellists (informed laymen) were asked to evaluate the following characteristics: overall appearance, smell (overall), smell (intensity), foreign smell, taste (overall), taste (intensity), aftertaste, consistency, overall impression after consumption. The assessments were on a 9-point hedonic scale ranging from 9 (like extremely) to 1 (dislike extremely) for each characteristic. The results of sensory evaluation from individual evaluators were recorded in a questionnaire and subsequently processed and evaluated in a graph.

\section{Statistical analysis}

All experiments were carried out in triplicate. The standard deviations for each replication were used for calculation of determined values. The experimental data were subjected to analysis of variance (Duncan's test) at the confidence level of 0.05 (SAS, 2009).

\section{RESULTS AND DISCUSSION}

\section{Determination of acid number}

Due to the high oil content, the seeds and products of them are subject to autooxidation. This process is undesirable and causes unpleasant odours and bitterness of the products. Oxidative and chemical changes in the oil are characterized by an increase in acid number (due to an increase in the free fatty acid content of the oil). This parameter indicates the amount of acidic substances produced by the oxidation of hydrocarbons. This means that the acid number directly determines the degree of oil degradation. Low endpoint values are desirable (Deáková, 2016). The measured values of the acid number of the tested

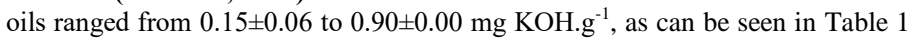
It can be seen from the evaluation of grape oils that all the grape oils tested had values below $1 \mathrm{mg} \mathrm{KOH} . \mathrm{g}^{-1}$. The highest value of acid number was determined in commercial oil and the lowest was determined in blue grape variety oil $\left(0.15 \pm 0.06 \mathrm{mg} \mathrm{KOH} . \mathrm{g}^{-1}\right)$. Among the Slovak variety, the highest acid number had a white grape variety oil sample, with a value of $0.64 \pm 0.07 \mathrm{mg} \mathrm{KOH} . \mathrm{g}^{-1}$. All samples of the tested oils met the requirements for the maximum permissible acid value of the ordinance, up to $4 \mathrm{mg} \mathrm{KOH} . \mathrm{g}^{-1}$ for virgin fats and oils. Similar results of acid number were also observed in study of Maszewska et al. (2018) their obtained values in grapeseed oil ranged from 0.3 to $0.39 \mathrm{mg} \mathrm{KOH.g}{ }^{-1}$.

Table 1 The results of acid number, peroxide number and fat content of analyzed samples

\begin{tabular}{|c|c|c|c|}
\hline Sample & $\begin{array}{l}\text { Acid number } \\
{\left[\mathrm{mg} \mathrm{KOH.} \mathrm{g}^{-1}\right]}\end{array}$ & $\begin{array}{c}\text { Peroxide } \\
\text { number } \\
{\left[\mathrm{mmol} \mathrm{O}_{2} \cdot \mathrm{kg}^{-1}\right]}\end{array}$ & $\begin{array}{c}\text { Fat content } \\
{[\%]}\end{array}$ \\
\hline Commercial oil & $0.90 \pm 0.11 \mathrm{a}$ & $8.91 \pm 1.05 \mathrm{a}$ & $98.23 \pm 2.32 \mathrm{a}$ \\
\hline $\begin{array}{l}\text { White grape } \\
\text { variety oil }\end{array}$ & $0.64 \pm 0.02 \mathrm{a}$ & $6.00 \pm 0.93 b$ & $96.00 \pm 2.49 \mathrm{a}$ \\
\hline $\begin{array}{l}\text { Blue grape } \\
\text { variety oil }\end{array}$ & $0.15 \pm 0.03 a$ & $2.75 \pm 0.14 \mathrm{c}$ & $95.86 \pm 1.68 \mathrm{a}$ \\
\hline $\begin{array}{l}\text { Grape oil after } \\
\text { fermentation }\end{array}$ & $0.56 \pm 0.12 \mathrm{a}$ & $3.75 \pm 0.11 \mathrm{c}$ & $97.46 \pm 1.33 \mathrm{a}$ \\
\hline
\end{tabular}

$\mathrm{KOH}$ - potassium hydroxide; mean \pm standard deviation; different letters in column denote mean values that statistically differ one from another

\section{Determination of peroxide number}

The peroxide number is another indicator of lipid oxidation or yellow oil evaluation. It characterizes the amount of peroxides and hydroperoxides formed by the action of air oxygen. Low value predetermines good stability of the sample 
against oxidative damage (Deáková, 2016). Parry et al. (2004) reported that the peroxide number and other indicators of the oxidation state of oils are highly dependent on the oil production method, which has been demonstrated in a study using a dry method of extracting grape seed oil. Oils obtained by microwave or dry heating had a much higher peroxide value $\left(5.6 \mathrm{mmol} \mathrm{O}_{2} \cdot \mathrm{kg}^{-1}\right)$ than those obtained by cold pressing $\left(1.9 \mathrm{mmol} \mathrm{O}_{2} \cdot \mathrm{kg}^{-1}\right)$. When evaluating grape oils (Table 1 ), it can be seen significant differences in peroxide value for each samples ranging from $2.75 \pm 0.50$ to $8.91 \pm 1.01 \mathrm{mmol} \mathrm{O}_{2} \cdot \mathrm{kg}^{-1}$. Commercial oil has a significantly higher value than Slovak grape oils, $8.91 \pm 1.01 \mathrm{mmol} \mathrm{O} \mathrm{O}_{2} \cdot \mathrm{kg}^{-1}$ Among the Slovak samples, the lowest value has the blue grape variety oil $\left(2.75 \pm 0.50 \mathrm{mmol} \mathrm{O}_{2} \cdot \mathrm{kg}^{-1}\right)$, the highest value, up to twice as high as blue grape variety oil, has the white grape variety oil sample $\left(6.00 \pm 0.25 \mathrm{mmol} \mathrm{O} \mathrm{O}_{2} \cdot \mathrm{kg}^{-1}\right)$. Al samples examined meet the requirements of the decree, which stipulates a peroxide value of not more than $15 \mathrm{mmol} \mathrm{O} \cdot \mathrm{kg}^{-1}$ for virgin fats and oils. In study of Maszewska et al. (2018) peroxide number in grapeseed oil ranged from 2.6 to $3 \mathrm{mmol} \mathrm{O}_{2} \cdot \mathrm{kg}^{-1}$, which is comparable with our results in case of blue grape variety and grape oil after fermentation.

\section{Determination of the amount of fat}

As we can see in Table 1, the fat content of the grape oil samples ranged from $95.86 \pm 1.68$ to $98.23 \pm 2.32 \%$. Significant differences are visible in grape oils commercial oil has the highest content of $98.23 \pm 2.32 \%$, while the lowest has blue grape variety oil of $95.86 \pm 1.68 \%$. Among Slovak oils, the highest fat content has grape oil after fermentation. Since the samples analyzed are cold pressed oils without refining, it is evident that these oils contain dyes, fiber, proteins - therefore the fat content is not $100 \%$.

Moreau et al. (2009) reported that pigments, such as carotenoids and chlorophylls, present in unrefined oils can reduce oil stability, although they can also be a positive attribute to provide an attractive colour.

\section{Determination of antiradical activity - DPPH method}

When comparing the antiradical activity of each type of grape oil, we observed considerable differences. Slovakian species achieved significantly higher values compared to the commercial oil, which reached $47.61 \pm 0.01 \mathrm{mg}$ TEAC.1 ${ }^{-1}$. The antiradical activity values of all samples are shown in Table 2. According to Du Toita et al. (2001) the DPPH method is considered one of the basic methods for assessing the antiradical activity of pure substances or solutions. The essence is the reaction of the test substance with a stable diphenylpicrylhydrazyl radical $(\mathrm{DPPH})$, in which the radical is reduced in reaction to give DPPH-H (diphenylpicrylhydrazine). This reaction is most often observed spectrophotometrically, measuring absorbance at $515 \mathrm{~nm}$. Konuskan et al. (2018) tested antioxidant activity of cold pressed grape oil (from variety Sirah, Merlot, Sangiovese, Cabernet Sauvignon and Sauvignon Blanc) by DPPH method. Higher activity was determined in their study in oils from blue grape varieties with the best results in oil from variety Merlot $(17.94 \%)$ following by variety Cabernet Sauvignon (15.32), Sirah (13.28\%) and Sangiovese (10.41\%) The lowest value was determined in oil from white grape variety Sauvignon Blanc $(7.04 \%)$.
Table 2 The results of antioxidant activity and oxidation stability of analyzed samples

\begin{tabular}{lcc}
\hline \hline Sample & $\begin{array}{c}\text { Antiradical } \\
\text { activity } \\
\text { [mg TEAC. } \text { I }^{-1} \text { ] }\end{array}$ & $\begin{array}{c}\text { Oxidation stability } \\
{[\mathbf{h}]}\end{array}$ \\
\hline Commercial oil & $47.61 \pm 0.21 \mathrm{~d}$ & $8.91 \pm 0.32 \mathrm{a}$ \\
White grape variety oil & $69.05 \pm 0.09 \mathrm{~b}$ & $6.00 \pm 0.04 \mathrm{~b}$ \\
Blue grape variety oil & $75.30 \pm 0.15 \mathrm{a}$ & $2.75 \pm 0.09 \mathrm{~d}$ \\
Grape oil after fermentation & $65.03 \pm 1.08 \mathrm{c}$ & $3.75 \pm 0.14 \mathrm{c}$ \\
\hline \hline
\end{tabular}

TEAC - Trolox equivalent antioxidant capacity; mean \pm standard deviation; different letters in column denote mean values that statistically differ one from another

\section{Determination of oxidation stability by Rancimat method}

Dyerberg et al. (2010) reported that unsaturated fats in fats are readily oxidized Oxidation products such as hydroperoxides and their breakdown products (aldehydes, ketones, organic acids) cause unwanted chemical or sensory changes in fat products, and the consumption of oxidized fats poses a health risk (free radical formation, lipoprotein oxidation, mutagenic changes in the body). Protection against oxidation consists in eliminating the adverse effects of fat oxidation. When comparing grape oils (Table 2), we can conclude that Slovak samples achieved lower values of oxidation stability than commercial oil. Slovak samples reached values from $2.75 \pm 0.09 \mathrm{~h}$ to $6.00 \pm 0.04 \mathrm{~h}$, while commercial oil reached the highest value of stability $-8.91 \pm 0.32 \mathrm{~h}$. Among the Slovakian, the longest induction time has reached white grape variety oil.

Generally the fastest oxidation of grapeseed oil can be explained by fatty acid composition. Grape oil contained approximately $68 \%$ polyunsaturated acids while for example peanut and rapeseed oils contained the smallest amounts of polyunsaturated acids (about 25-28\%, respectively) (Maszewska et al., 2018). Oxidative stability of oils is also influenced by antioxidants. The content of sterols in vegetable oils is from 70 to $1100 \mathrm{mg} .100 \mathrm{~g}^{-1}$ of oil. Most of these compounds are found in corn oil, then slightly less in rapeseed oil $\gamma$-oryzanol in rice bran and tocotrienols and tocopherols in grapeseed and rice bran oils (Ratisz et al. 2016).

\section{Determination of fatty acid methyl esters content by GC-FID method}

The predominant acid in all samples was linoleic acid (Table 3). Its conten differed from $69.43 \pm 0.00 \%$ in commercial oil to $72.75 \pm 0.04 \%$ in blue grape variety oil. Elaidic acid was the least represented in the case of white grape variety oil and grape oil after fermentation. In commercial oil was identified linolelaidic acid in an amount of $0.64 \pm 0.00 \%$, which was also the least represented acid in this oil sample and which was not found in the other grape oil samples. Equally, essential $\alpha$-linolenic acid was identified in the blue grape variety oil at $0.43 \pm 0.00 \%$, while in other samples it was not identified. Other acids found in grape oils without major differences were oleic acid, palmitic acid and stearic acid. When comparing the oils from the point of view of origin, we can say that there are no significant differences in the content of individual types of fatty acids. However, linolelaidic acid, which was not found in Slovak samples, is also present in commercial oil.

In study of Maszewska et al., (2018) corn and grapeseed oils contained $28.8 \%$ and $18.8 \%$ of monoenic acids. In their study was also published that the largest share of polyene acids were found in grapeseed oil $(68.4 \%)$. From a nutritional point of view, the content of polyene fatty acids in oils is a desirable feature. On the other hand, oils of this composition are not very resistant to external factors, they are very susceptible to oxidation e.g. $\alpha$-linolenic acid. There is concern that long-term consumption of large amounts of this acid can increase cancer risk (Hart et al., 2009).

Table 3 The results of fatty acid methyl esters content of analyzed samples

\begin{tabular}{|c|c|c|c|c|}
\hline Sample & $\begin{array}{l}\text { White variety grape oil } \\
{[\%]}\end{array}$ & $\begin{array}{l}\text { Blue variety grape oil } \\
{[\%]}\end{array}$ & $\begin{array}{l}\text { Grape oil after fermentation } \\
{[\%]}\end{array}$ & $\begin{array}{l}\text { Commercial oil } \\
{[\%]}\end{array}$ \\
\hline C16: 0 & $8.43 \pm 0.02 \mathrm{a}$ & $7.81 \pm 0.05 \mathrm{~b}$ & $7.66 \pm 0.02 b$ & $7.48 \pm 0.03 \mathrm{~b}$ \\
\hline C18: 0 & $3.83 \pm 0.00 \mathrm{a}$ & $3.96 \pm 0.00 \mathrm{a}$ & $3.73 \pm 0.01 \mathrm{~b}$ & $3.87 \pm 0.01 \mathrm{a}$ \\
\hline C18: $\ln 9 c$ & $17.35 \pm 0.00 \mathrm{a}$ & $14.34 \pm 0.01 b$ & $15.55 \pm 0.00 \mathrm{~b}$ & $17.84 \pm 0.02 \mathrm{a}$ \\
\hline C18: $\ln 9 t$ & $0.83 \pm 0.00 \mathrm{a}$ & $0.70 \pm 0.00 \mathrm{~b}$ & $0.78 \pm 0.00 \mathrm{~b}$ & $0.75 \pm 0.00 b$ \\
\hline$C 18: 2 n 6 t$ & $0.00 \pm 0.00 \mathrm{~b}$ & $0.00 \pm 0.00$ & $0.00 \pm 0.00 \mathrm{~b}$ & $0.64 \pm 0.00 \mathrm{a}$ \\
\hline$C 18: 2 n 6 c$ & $69.57 \pm 0.02 b$ & $72.75 \pm 0.04 a$ & $72.28 \pm 0.01 \mathrm{a}$ & $69.43 \pm 0.00 \mathrm{~b}$ \\
\hline C18: $3 n 3 c$ & $0.00 \pm 0.00 \mathrm{~b}$ & $0.43 \pm 0.00 \mathrm{a}$ & $0.00 \pm 0.00 \mathrm{~b}$ & $0.00 \pm 0.00 \mathrm{~b}$ \\
\hline
\end{tabular}

mean \pm standard deviation; $\mathrm{C} 16: 0=$ palmitic acid, $\mathrm{C} 18: 0=$ stearic acid, $\mathrm{C} 18: 1 \mathrm{n} 9 \mathrm{c}=$ oleic acid, $\mathrm{C} 18: 1 \mathrm{n} 9 \mathrm{t}=$ elaidic acid, $\mathrm{C} 18: 2 \mathrm{n} 6 \mathrm{t}=\mathrm{linolelaidic}$ acid,

$\mathrm{C} 18: 2 \mathrm{n} 6 \mathrm{c}=$ linoleic acid, $\mathrm{C} 18: 3 \mathrm{n} 3 \mathrm{c}=\alpha$-linolenic acid; different letters in column denote mean values that statistically differ one from another

Determination of antibacterial and antifungal properties of edible vegetable oils by selected microorganisms using disc diffusion method

Bacillus cereus is an aerobic or facultatively anaerobic, $\mathrm{G}^{+}$, rod-shaped bacterium sporulating from the Bacillaceae family that occurs in soil and water (Cammack et al., 2006). Staphylococcus aureus subs. aureus belongs to the genus $\mathrm{G}^{+}$, facultatively anaerobic, cocoid bacteria, the Micrococcaceae family. It occurs on the skin and mucous membranes of humans and animals. Staphylococcus aureus may be responsible for food poisoning due to the consumption of contaminated foods such as meat and meat products, eggs, salads, bakery and dairy products (IFIS, 2009). Grape seed oil has a toxicity effect on some pathogens, suggesting an antimicrobial feature. In fact, the oil extracted from grape seeds had an 
inhibitory effect on the growth of Staphylococcus aureus and Escherichia coli (Baydar et al., 2006; Rotava et al., 2009). The antimicrobial activity displayed by phenolic compounds, such as resveratrol, involves the induction of oxidative damage to bacterial membrane, especially E. coli, without affecting the host cells. These findings suggest that the use of resveratrol would aid traditional therapies in which antibiotics are ineffective (Subramanian et al., 2014). Bacillus cereus is an aerobic or facultatively anaerobic, $\mathrm{G}^{+}$, rod-shaped bacterium sporulating from the Bacillaceae family that occurs in soil and water (Cammack et al., 2006). Staphylococcus aureus subs. aureus belongs to the genus $\mathrm{G}^{+}$, facultatively anaerobic, cocoid bacteria, the Micrococcaceae family. It occurs on the skin and mucous membranes of humans and animals. Staphylococcus aureus may be responsible for food poisoning due to the consumption of contaminated foods such as meat and meat products, eggs, salads, bakery and dairy products (IFIS 2009). Grape seed oil has a toxicity effect on some pathogens, suggesting an antimicrobial feature. In fact, the oil extracted from grape seeds had an inhibitory effect on the growth of Staphylococcus aureus and Escherichia coli (Baydar et al., 2006; Rotava et al., 2009). The antimicrobial activity displayed by phenolic compounds, such as resveratrol, involves the induction of oxidative damage to bacterial membrane, especially $E$. coli, without affecting the host cells. These findings suggest that the use of resveratrol would aid traditional therapies in which antibiotics are ineffective (Subramanian et al., 2014). Yersinia enterocolitica belongs to the family of facultatively anaerobic, rod-shaped, $\mathrm{G}$ bacteria of the Enterobacteriaceae family. It occurs in soil and water, in the gastrointestinal tract of animals (such as pigs and rodents). Some species are able to survive and reproduce even at low temperatures, so they can pose a danger to refrigerant foods (IFIS, 2009). Salmonella enterica subs. enterica belongs to facultative anaerobic, rod-shaped, Gbacteria, Enterobacteriaceae. It occurs mainly in soil, water and food (eg raw meat and seafood, eggs, dairy products) and in the gastrointestinal tract of humans and animals (especially poultry and pigs) (Cammack et al., 2006).

Candida albicans belongs to the yeast genus, the class of Saccharomyces. It occurs in soil and on plants (IFIS, 2009). Palma et al. (1999) carried out a study, where grape seeds were exerted the strongest antimicrobial action against $S$ coagulans E.cloacae, C. freundii and E.coli. The later bacteria were sensitive to all tested concentrations of fraction A, even the lowest one. S. aureus was only moderately sensitive to the highest concentration. B. cereus and the fungus $A$. flavus were resistant to fraction A at every concentration

Table 4 The results of antimicrobial activity against $\mathrm{G}^{+}[\mathrm{mm}]$

\begin{tabular}{|c|c|c|c|c|}
\hline Sample & $\begin{array}{c}\text { Bacillus cereus } \\
\text { CCM } 2010\end{array}$ & $\begin{array}{c}\text { Staphylococcus aureus } \\
\text { subs. aureus } \\
\text { CCM } 2461\end{array}$ & $\begin{array}{l}\text { Clostridiun } \\
\text { perfringens } \\
\text { CCM } 4435\end{array}$ & $\begin{array}{c}\text { Streptococcus } \\
\text { pneumoniae } \\
\text { CCM } 4501\end{array}$ \\
\hline Commercial oil & $4.33 \pm 2.08 \mathrm{ab}$ & $5.33 \pm 0.53 a$ & $3.00 \pm 1.73 \mathrm{a}$ & $0.10 \pm 0.01 \mathrm{~b}$ \\
\hline $\begin{array}{l}\text { White grape variety } \\
\text { oil }\end{array}$ & $3.67 \pm 2.08 \mathrm{ab}$ & $2.33 \pm 0.58 b$ & $2.67 \pm 0.58 \mathrm{a}$ & $0.00 \pm 0.00 \mathrm{c}$ \\
\hline Blue grape variety oil & $6.67 \pm 0.58 \mathrm{a}$ & $4.67 \pm 0.58 \mathrm{a}$ & $2.00 \pm 0.00 \mathrm{a}$ & $0.00 \pm 0.00 \mathrm{c}$ \\
\hline $\begin{array}{l}\text { Grape oil after } \\
\text { fermentation }\end{array}$ & $2.67 \pm 0.58 b$ & $4.33 \pm 0.58 \mathrm{a}$ & $2.33 \pm 0.58 \mathrm{a}$ & $0.13 \pm 0.03 \mathrm{a}$ \\
\hline
\end{tabular}

mean \pm standard deviation; different letters in column denote mean values that statistically differ one from another

Table 5 Results of antimicrobial activity against $\mathrm{G}^{-}[\mathrm{mm}]$

\begin{tabular}{|c|c|c|c|c|c|}
\hline Sample & $\begin{array}{c}\text { Klebsiella } \\
\text { pneumoniae } \\
\text { CCM } 2318\end{array}$ & $\begin{array}{c}\text { Yersinia enterocolitica } \\
\text { CCM } 5671\end{array}$ & $\begin{array}{c}\text { Haemophilus } \\
\text { influenzae } \\
\text { CCM } 4456\end{array}$ & $\begin{array}{c}\text { Salmonella enterica } \\
\text { subs. enterica } \\
\text { CCM } 3807\end{array}$ & $\begin{array}{c}\text { Escherichia coli } \\
\text { CCM } 3954\end{array}$ \\
\hline Commercial oil & $2.33 \pm 0.58 \mathrm{a}$ & $2.67 \pm 1.15 b c$ & $0.03 \pm 0.06 \mathrm{c}$ & $2.67 \pm 1.15 \mathrm{a}$ & $0.13 \pm 0.01 \mathrm{a}$ \\
\hline $\begin{array}{l}\text { White grape } \\
\text { variety oil }\end{array}$ & $1.67 \pm 0.58 \mathrm{a}$ & $2.00 \pm 0.00 \mathrm{c}$ & $0.00 \pm 0.00 \mathrm{c}$ & $4.00 \pm 1.73 \mathrm{a}$ & $0.03 \pm 0.01 \mathrm{c}$ \\
\hline $\begin{array}{l}\text { Blue grape } \\
\text { variety oil }\end{array}$ & $2.33 \pm 0.58 \mathrm{a}$ & $3.00 \pm 1.00 \mathrm{ab}$ & $0.07 \pm 0.01 \mathrm{~b}$ & $2.00 \pm 1.00 \mathrm{a}$ & $0.00 \pm 0.00 \mathrm{~d}$ \\
\hline $\begin{array}{l}\text { Grape oil after } \\
\text { fermentation }\end{array}$ & $1.67 \pm 0.58 \mathrm{a}$ & $4.33 \pm 0.58 \mathrm{a}$ & $0.17 \pm 0.02 \mathrm{a}$ & $2.67 \pm 0.58 \mathrm{a}$ & $0.07 \pm 0.12 b$ \\
\hline
\end{tabular}

mean +standard deviation; different letters in column denote mean values that statistically differ one from another

Table 6 Results of antifungal activity [mm]

\begin{tabular}{lcccc}
\hline \hline Sample & White variety grape oil & Blue variety grape oil & Grape oil after fermentation & Commercial oil \\
\hline $\begin{array}{l}\text { Candida } \\
\text { albicans } \\
\text { CCM 8186 }\end{array}$ & $0.10 \pm 0.01 \mathrm{a}$ & $0.0 \pm 0.00 \mathrm{~b}$ & $0.03 \pm 0.01 \mathrm{~b}$ & $0.10 \pm 0.0 .01 \mathrm{a}$ \\
\hline \hline
\end{tabular}

mean \pm standard deviation; different letters in column denote mean values that statistically differ one from another

\section{Sensory evaluation of oil}

We can conclude that the overall appearance was evaluated for all samples with high values. The worst rating was grape oil after fermentation with a value of 7.15. The presence of a foreign smell was most present in grape oil after fermentation a 6.00 point. From the point of view of consistency, all oils achieved a high rating from 7.23 to 8.31 points, the highest value attributed to white grape variety oil.

Blue grape variety oil was characterized by its dark green colour and typical grape aroma and taste. There was also a foreign smell characterized as being gently beer, acidic, to rubber after oxidation. The oil also left a sour, beer or metal aftertaste.

White grape variety oil was light green colour, alcoholic, wine odour. scent of mussels and herbs. In addition to the grapes, the taste was slightly soft and the wine was slightly scraped in the throat. Grape oil after fermentation, had a dark green colour, characterized by a wine, acetic, ethanol or alcohol flavour, similar to that of the B-complex. The aftertaste has been characterized as alcoholic, liqueur, vinous, drug-like or nail polish, characterized by consumers as being unsuitable for oil.

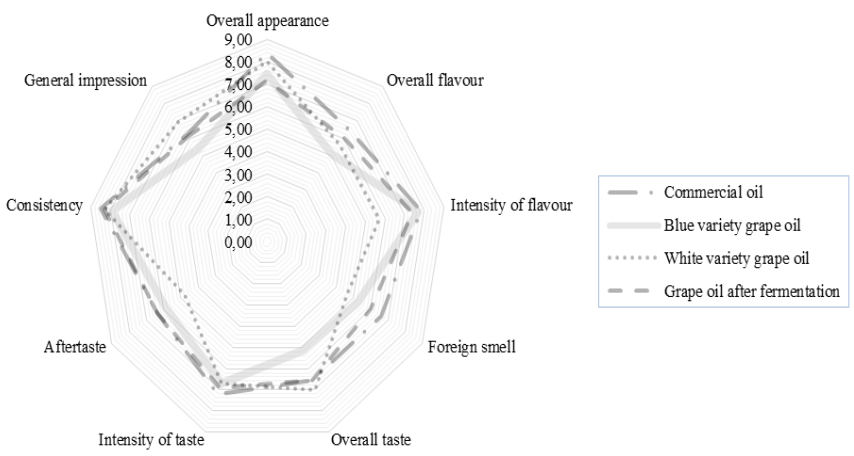

Figure 1 Sensory evaluation of oil

Commercial oil smelled of the presence of foreign smells of alcohol or fermented grapes. The scent was, according to the evaluators, unpleasant, acidic, burgundy or yeast, and some had a balsamic vinegar smell. The evaluators noted slightly alcoholic, yeast to sweetish aftertaste that caused sore throat. The colour was gently green.

Colour is a qualitative property that significantly affects the consumer's oil rating. Green pigments, in particular chlorophyll content, impart undesirable colour to 
berry plant vegetable oils and can also promote oxidation thereof (Gutiérrez $\boldsymbol{e t}$. al., 2007).

\section{CONCLUSION}

The results of our study point to a higher quality of local Slovak types of grape oils compared to commercial oil, the reason could be higher quality of raw material, well-chosen variety of crop or harvesting method. The quality of grape oils is characterized by very low acidity values, as an important indicator of fat and oil status, the lowest measured value of $0.15 \pm 0.06 \mathrm{mg} \mathrm{KOH} . \mathrm{g}^{-1}$ in blue grape variety oil. The peroxide number characterizing the content of peroxides and hydroperoxides formed by the undesirable oxidation process, which negatively affects the quality or nutritional value of the oil, was characterized by significant differences between the grape variety of oil, values from $2.75 \pm 0.50$ $\mathrm{mmol} \mathrm{O}{ }_{2} \mathrm{~kg}^{-1}$ (blue grape variety oil) to $6.00 \pm 0.25 \mathrm{mmol} \mathrm{O}_{2 .} \mathrm{kg}^{-1}$ (white grape variety oil). The antioxidant activity of the oils was measured by the DPPH radical with which the antioxidants present in the oil reacted. The highest value of $75.30 \pm 0.00 \mathrm{mg}$ TEAC. $\mathrm{l}^{-1}$ was achieved in blue grape variety oil. With the GC-FID method, have been determined the fatty acid content of individual oil samples and the measurement is also interesting from the point of view of the presence of essential fatty acids. Omega- 6 fatty acid linoleic had the highes proportion in blue grape variety oil at $72.75 \pm 0.04 \%$ and $\alpha$-linolenic acid was also recorded. In commercial oil omega- 6 fatty acid linoelaide was present, which was not present in another oil samples. The measurements also confirmed the anibacterial and antifungal properties of vegetable oils. The greatest inhibition in $\mathrm{G}^{+}$bacteria was recorded on Bacillus cereus, in blue grape variety oil. In sensory evaluation, the best overall impression was achieved by the white grape variety oil and the least points by the blue grape variety oil. All tested grape oil samples comply with the requirements of the Food Code of the Slovak Republic.

Acknowledgments: Work was supported by Research Center AgroBioTech built in accordance with the project Building Research Center „AgroBioTech“ ITMS 26220220180

\section{REFERENCES}

Augustín, J. (2010). Plant and Animal Oils and Technical Oils. Epicure, 4(17), 40-49.

Babinská, K., \& Béderová, A. (2012). The Importance of Fats and Their Consumption in Population SR. Bratislava: Institute of Physiology LF UK, 3238.

Baydar, N. G., Sagdic, O., Ozkan, G., \& Cetin, S. (2006). Determination of antibacterial effects and total phenolic contents of grape (Vitis viniferaL.) seed extracts. International Journal of Food Science \& Technology, 41(7), 799-804. https://doi.org/10.1111/j.1365-2621.2005.01095.x.

Cammack, R., Attwood, T. K., Campbell, P. N., Parish, J. H., Smith, A. D., Stirling, J. L., \& Vella, F. (2006). Oxford Dictionary of Biochemistry and Molecular Biology. New York: Oxford University Press, 2.

Deáková, L. (2016). Chemické zloženie a oxidačná stabilita semien a oleja maku siateho (Papaver somniferum L.). Mak siaty pre Slovensko Piešt’any : NPPC, VÚRV, 28-29.

Du Toit, R., Volsteedt, Y., \& Apostolides, Z. (2001). Comparison of the antioxidant content of fruits, vegetables and teas measured as vitamin C equivalents. Toxicology, 166(1-2), 63-69. https://doi.org/10.1016/s0300483x(01)00446-2.

Dyerberg, J., Madsen, P., Møller, J. M., Aardestrup, I., \& Schmidt, E. B. (2010) Bioavailability of marine n-3 fatty acid formulations. Prostaglandins, Leukotrienes and Essential Fatty Acids, 83(3), 137-141. https://doi.org/10.1016/j.plefa.2010.06.007.

EFISC GUIDE (2014). Sector reference document on the manufacturing of safe feed materials from oilseed crushing and vegetable oil refining. Brussels: EFISC Aisbl., 162.

Gutiérrez, F., Jímenez, B., Ruíz, A., \& Albi, M. A. (1999). Effect of Olive Ripeness on the Oxidative Stability of Virgin Olive Oil Extracted from the Varieties Picual and Hojiblanca and on the Different Components Involved. Journal of Agricultural and Food Chemistry, 47(1), 121-127. https://doi.org/10.1021/jf980684i.

IFIS (2009!. Dictionary of Food Science and Technology. Singapur : IFIS Publishing - International Food Information Service, 2.

Hart, A., Tjonneland, A., Olsen, A., Overvad, K., Bergmann, M.M., Boeing, H., Nagel, G., Linseisen, J., HallmansS, G., \& Danielsson, Å. (2009). Linoleic acid, a dietary n-6 polyunsaturated fatty acid, and the aetiology of ulcerative colitis: a nested case-control study within a European prospective cohort study. Gut, 58(12), 1606-1611. https://doi.org/10.1136/gut.2008.169078.

INSTITUTE OF SHORTENING AND EDIBLE OILS, INC, ISEO. (2016). Food fats and oils. Washington, DC. 3.

Konuskan, D. B., Kamiloglu, O., \& Demirkeser, O. (2019). Fatty Acid Composition, Total Phenolic Content and Antioxidant Activity of Grape Seed Oils Obtained by Cold- Pressed and Solvent Extraction. Indian Journal of
Pharmaceutical Education and Research, 53(1), 144-150 https://doi.org/10.5530/ijper.53.1.19.

Moreau, R. A., \& Kamal-Eldin, A. (2009). Gourmet and Health-Promoting Specialty Oils, AOCS Press.

Maszewska, M., Florowska, A., Dłużewska, E., Wroniak, M., MarciniakLukasiak, K., \& Żbikowska, A. (2018). Oxidative Stability of Selected Edible Oils. Molecules, 23(7), 1746. https://doi.org/10.3390/molecules23071746.

Ogrodowska, D., Tańska, M., \& Brandt, W. (2017). The Influence of Drying Process Conditions on the Physical Properties, Bioactive Compounds and Stability of Encapsulated Pumpkin Seed Oil. Food and Bioprocess Technology, 10(7), 1265-1280. https://doi.org/10.1007/s11947-017-1898-Z.

Palma, M., Taylor, L. T., Varela, R. M., Cutler, S. J., \& Cutler, H. G. (1999) Fractional Extraction of Compounds from Grape Seeds by Supercritical Fluid Extraction and Analysis for Antimicrobial and Agrochemical Activities. Journa of Agricultural and Food Chemistry, 47(12), 5044-5048. https://doi.org/10.1021/jf990019p.

Parry, J., \& Yu, L. (2006). Fatty Acid Content and Antioxidant Properties of Cold-pressed Black Raspberry Seed Oil and Meal. Journal of Food Science, 69(3), FCT189-FCT193. https://doi.org/10.1111/j.1365-2621.2004.tb13356.x.

Příbela, A. (1993). Analýza potravín. Bratislava: STU, 2., 394.

Ratusz, K., Popis, E., Ciemniewska-Żytkiewicz, H., \& Wroniak, M. (2016) Oxidative stability of camelina (Camelina sativa L.) oil using pressure differential scanning calorimetry and Rancimat method. Journal of Thermal Analysis and Calorimetry, 126(1), 343-351. https://doi.org/10.1007/s10973-016$\underline{5642-0 .}$.

Rotava, R., Zanella, I., \& Da Silva, L.P. (2009). Antibacterial, antioxidant and tanning activity of grape by product. Ciencia Rural, 39, 941-944.

SAS. Users Guide Version 9.2. SAS/STAT (r). SAS Institute Inc. Cary, NC, USA. 2009.

Sánchés-Moreno, C., Larrauri, A., \& Saura-Calixto, F.A. (1998). The procedure to measure the antioxidant efficiency of polyphenols. Journal of the Science of Food and Agriculture, 76, 270-276. https://doi.org/10.1002/(sici)10970010(199802)76:2<270::aid-jsfa945>3.0.c0;2-9.

Subramanian, M., Goswami, M., Chakraborty, S., \& Jawali, N. (2014) Resveratrol induced inhibition of Escherichia coli proceeds via membrane oxidation and independent of diffusible reactive oxygen species generation. Redox Biology, 2, 865-872. https://doi.org/10.1016/j.redox.2014.06.007. 